\section{City and Guilds of London Institute}

AT a special general meeting of the members of the City and Guilds of London Institute, held at Skinners' Hall on September 21, H.R.H. the Duke of Edinburgh was elected president. The first president was King Edward VII, when Prince of Wales; but on his accession to the throne he became visitor in accordance with the Institute's Royal Charter granted in 1900, and the office had since remained vacant. This further connexion with the Royal Family is a high tribute to the Institute's independent work extending over a period of seventy years. It is also a reminder that much still remains to be done by all concerned with scientific and technological education, as the Duke of Edinburgh so clearly indicated in his presidential address to the British Association this year.

The Institute was founded by the Corporation and certain of the Livery Companies of the City of London in 1878, during the period which His Royal Highness described as the high-water mark of British industrial expansion. There was a great need for better scientific and technical grounding for those engaged in industry, and the Institute accordingly set itself to meet this need by founding Finsbury Technical College, the Central Institution (now the City and Guilds College) and the Art School at Kennington. Concurrently the Institute, having taken over the technical examinations of the Royal Society of Arts, began to build up the Department of Technology, the syllabuses and certificates of which are so well known to industry and to countless students and teachers in technical colleges. This is a long list to the credit of one body, and the common parentage is not always appreciated. The influence of each, from craft to professional level, on technological training and education has been considerable. 'This year recalls the 1851 Exhibition, which was also of practical significance to the Institute, for the City and Guilds College is among the educational institutions built on the site purchased with the proceeds of that great enterprise of Prince Albert.

\section{United Nations Technical Assistance to Under- developed Countries}

IN view of the demands which the Colombo Plan and other schemes for technical assistance to the underdeveloped areas of the world may make upon British and other resources, particularly in scientific and technical man-power, the pamphlet "United Nations Work and Programmes for Technical Assistance" (pp. 40; New York: United Nations ; London: H.M. Stationery Office; $1951 ; 15$ cents. $1 s$.$) , issued$ by the United Nations Department of Public Information, makes a welcome appearance. Its forty pages contain a clear explanation of what is meant by technical assistance, how the programme came into being, the principles which determine the selection of experts or of projects, the way in which the programme works and is administered, and where the particular responsibilities lie, as well as the way in which it is related to other programmes of technical assistance. An annexe records the technical assistance given in 1950, including the countries aided, and a brief bibliography indicates where further information about the technical assistance work of the United Nations and the Specialized Agencies may be found. The pamphlet is strictly factual and should assist in the discussions of a subject that, as the recent report of the Advisory Council on Scientific
Policy indicates, is likely to become increasingly important. While it outlines what is required of the assisted countries and should help to keep discussion free from prejudice, there is one important omission which doubtless is unavoidable in a pamphlet of this nature and length : it does not indicate the factors, such as population pressure, which may determine, independently of the merits of the programmes themselves, the success or failure of technical assistance. Such factors must receive full recognition in deciding on the allocation of limited scientific and technical resources, whether from the United Kingdom or elsewhere.

\section{Natural Resources of Canada: Annual Depart- mental Report for 1948-49}

The report of the Mines, Forests and Scientific Services Branch of the Department of Mines and Resources, Canada, for the year ended March 31, 1949 (pp. 117; Ottawa: King's - Printer, 1950), which has been reprinted from the Department's annual report, covers the activities of the Bureau of Mines, Dominion Forest Service, Geological Survey of Canada, Surveys and Mapping Bureau, Dominion Water and Power Bureau, Geographical Bureau, National Museum of Canada and the Dominion Observatories. Special stress is laid upon the con. tinued success of drilling operations in the new oilfields in Alberta, and Canada's dependence on foreign supplies is expected to diminish considerably; besides a large increase in production for 1949, a considerable expansion of refining facilities was anticipated. Closely related to these developments are developments with natural gas which may markedly affect the economy of the country. There were also important developments in relation to iron ore, titanium and uranium. The salt industry continued to expand, as well as the forest industry, and exports of pulp and paper attained new records. Increasing attention is being given to the depletion of forests, and especially to more efficient utilization of the hewn wood, but losses through forest fires were again high. The Geological Survey's facilities for assisting in the search for radioactive minerals were extended, as well as those of its Geophysical Section for dealing with the plotting of magnetic data acquired with the airborne magnetometer. A pilot plant for the separation of bitumen from the bituminous sand of northern Alberta was ready for operation at the end of the year, and the practicability of structural steel welding in Canada under winter conditions has been demonstrated. Work on the use of red-stained jackpine in sleepers and poles is likely to conserve timber supplies, and the Surveys and Mapping Bureau has been considerably expanded to meet the increased demand for maps in the study and development of Canada's natural resources.

\section{Training for Social Work}

AN international survey of training for social work has been prepared by the United Nations Department of Social Affairs to provide the Social Commission and the Economic and Social Council with a detailed description and analysis of the methods of training of social workers in various countries. The study is based on reports submitted to the United Nations Secretariat and analyses the various conceptions of social work revealed in the definitions submitted. It also contains a survey of the general systems of education for social work that have been evolved for 